\title{
Influence of Protein C Activation on Blood Coagulation and Fibrinolysis in Squirrel Monkeys
}

\author{
M. Colucci, J. M. Stassen, and D. Collen \\ Center for Thrombosis and Vascular Research, Department of \\ Medical Research, University of Leuven, Belgium
}

bstract. Protein $\mathrm{C}$ is a circulating proenzyme which, upon activation, exerts a potent anticoagulant activity. Infusion of activated bovine protein $\mathrm{C}$ into dogs is accompanied by an increase of circulating tissue plasminogen activator (PA) activity. However, the evidence that human protein $C$ shares a similar profibrinolytic capacity is still lacking. Therefore, we investigated the profibrinolytic properties of human protein $\mathrm{C}$ in squirrel monkeys (Samiri sciureus).

Injection of activated human protein $\mathrm{C}$ resulted in prolongation of the activated partial thromboplastin time but was not associated with increased fibrinolytic activity of blood. Similarly, activation of endogenous protein $\mathrm{C}$ (up to 20-30\%) by infusion of thrombin-thrombomodulin complex markedly reduced blood coagulability without being accompanied by an increase of circulating PA activity.

The in vivo-generated anticoagulant activity was identified as activated protein $\mathrm{C}$ by the following observations. It was neutralized by rabbit anti-human protein C-IgG, was slowly inhibited by plasma but not by antithrombin III, was adsorbable on barium citrate, and expressed amidolytic activity. Activation of protein $\mathrm{C}$ appeared to be selective since other parameters such as thrombin time, platelet count, fibrinogen, and factor $\mathrm{V}$ levels were unaffected by thrombin-thrombomodulin infusion. Infusion of human plasma derived from whole

Dr. Colucci's permanent address is Istituto di Richerche Framacologiche "Mario Negri," Via Eritrea 62, 20157 Milano, Italy. Address all correspondence to Dr. Collen, Center for Thrombosis and Vascular Research, Department of Medical Research, Campus Gasthuisberg-K. U. Leuven, Herestraat 49, B-3000 Leuven, Belgium.

Received for publication 27 December 1983 and in revised form 22 March 1984.

J. Clin. Invest.

(c) The American Society for Clinical Investigation, Inc.

0021-9738/84/07/0200/05 \$1.00

Volume 74, July 1984, 200-204 blood incubated in vitro with human activated protein $\mathrm{C}$ also did not induce a fibrinolytic response, suggesting that no second messengers with PA-releasing activity were being generated in blood.

It is concluded that in a primate, neither the administration of activated human protein $\mathrm{C}$ nor the activation of endogenous protein $\mathrm{C}$ are associated with an increase of fibrinolytic activity. These findings question the role of this enzyme in the regulation of PA release in man.

\section{Introduction}

Protein $\mathrm{C}(\mathrm{PC})^{1}$ is a vitamin $\mathrm{K}$-dependent plasma protein which, in the active form (PCa), exerts anticoagulant activity (1) by degrading factors Va and VIIIa (2). Activation of PC occurs via proteolytic cleavage of the molecule by a complex between thrombin and an endothelial cell cofactor, thrombomodulin (3).

PCa has been demonstrated to express profibrinolytic activity in vitro and in vivo $(4,5,6)$. Infusion of bovine $\mathrm{PCa}$ into dogs resulted in increased levels of plasminogen activator (PA) in blood (4). Increase of circulating PA has also been observed in dogs following activation of endogenous PC by infusion of low doses of thrombin (5). In vitro, the rate of blood clot lysis induced by tissue PA was markedly enhanced in the presence of PCa (6). Because of its anticoagulant and profibrinolytic properties, PC may play a primary role in the regulation of hemostasis. Some studies (7), however, have indicated that species specificity may be an important determinant in the expression of the biological properties of PC.

To eliminate species variability as much as possible and to obtain information which may be more relevant to man, we investigated the profibrinolytic properties of human PC in squirrel monkeys.

1. Abbreviations used in this paper: APTT, activated partial thromboplastin time; DDAVP, 1-desamino 8-D arginine vasopressin; FV, coagulation factor V; PA, plasminogen activator; PC, protein C; PCa, activated protein C; T-TM, thrombin-thrombomodulin; TT, thrombin time. 


\section{Methods}

Purified proteins. Human PC was purified from human factor IX complex (Hyland Therapeutic Division, Travenol Laboratories, Glendale, CA; courtesy of Dr. R. A. De Vreker) as described by Sala et al. (8). Human $\alpha$-thrombin $(2,560 \mathrm{U} / \mathrm{mg})$ was a generous gift of Dr. J. W. Fenton (Division of Laboratories and Research, New York State Department of Health, Albany, NY) (9). Thrombomodulin was prepared by extraction of homogenized rabbit or monkey lungs and chromatography on Diisopropyl-phosphoro-thrombin-Sepharose as described previously (10). Final preparations were in Tris- $\mathrm{HCl}$ buffer containing $0.01 \%$ Tween 80 instead of Triton X-100. Thrombomodulin concentration was determined by titration with thrombin. Antithrombin III and high affinity heparin were purified as described elsewhere (11). PC (200 $\mu \mathrm{g} / \mathrm{ml})$ was activated with human $\alpha$-thrombin (at an enzyme-substrate weight ratio of 1:50) at $37^{\circ} \mathrm{C}$. After maximal amidolytic activity was generated (generally after $2 \mathrm{~h})$, thrombin was neutralized by antithrombin III $(10 \mu \mathrm{g} / \mathrm{ml})$ and high affinity heparin $(0.025$ units $/ \mathrm{ml})$. Thrombin-thrombomodulin (T-TM) complex was prepared by incubating the two proteins (at $0.75-$ $0.80 \mathrm{M}$ ratio) for $5 \mathrm{~min}$ at $37^{\circ} \mathrm{C}$. Residual thrombin clotting activity was $<3 \%$. Rabbit Ig directed against human melanoma cell tissue-type PA and human urokinase were prepared as described elsewhere (12). Rabbit anti-human PC antiserum was a gift of Dr. J. Stenflo (Department of Clinical Chemistry, University of Lünd, Malmö, Sweden). IgG from the antiserum were purified by chromatography on protein A-Sepharose (13).

In vivo experiments. Female squirrel monkeys (Samiri sciureus, South American Primates, Inc., Miami, FL) weighing 0.5-0.7 kg were used. They were anesthetized by intramuscular injection of ketamine hydrochloride $(25 \mathrm{mg} / \mathrm{kg})$ and of atropine $(0.06 \mathrm{mg} / \mathrm{kg})$ followed by intravenous injection of pentobarbital $(30 \mathrm{mg} / \mathrm{kg})$. Infusions were given via a superficial foreleg vein and blood samples were taken by puncture from a femoral vein. Blood samples $(9 \mathrm{vol})$ were anticoagulated with $4 \%$ trisodium citrate ( $1 \mathrm{vol})$ and kept on ice until processed. Blood volume was estimated as $60 \mathrm{ml} / \mathrm{kg}$ body weight.

Laboratory test. Activated partial thromboplastin time (APTT) thrombin time (TT), fibrin polymerization time, coagulation factor $V$ (FV) assay, and platelet count were carried out by routine laboratory techniques. PA activity was measured by the fibrin plate method (14) as reported (12). Blood fibrinolytic activity was also evaluated by measuring the release of ${ }^{125} \mathrm{I}$-fibrin degradation products from radiolabeled blood clots. Citrated whole blood was transferred into a $12 \times 55-\mathrm{mm}$ polystyrene tube and $10 \mu \mathrm{l}{ }^{125}$ I-fibrinogen solution $(1 \mathrm{mg} / \mathrm{ml}, \sim 50$ $\mathrm{Ci} / \mathrm{mg})$ plus $50 \mu \mathrm{l}$ thrombin $(25 \mathrm{U} / \mathrm{ml})$ were added. The sample was incubated for $10 \mathrm{~min}$ at room temperature and then the clotted blood was freed from the wall of the tube by rimming it with a glass rod. After an additional $30-\mathrm{min}$ incubation at $37^{\circ} \mathrm{C}$, the clot was removed and transferred into a petri dish containing $20 \mathrm{ml}$ of $20 \mathrm{mM}$ Tris- $\mathrm{HCl}, 130$ $\mathrm{mM} \mathrm{NaCl}$ buffer, $\mathrm{pH}$ 7.4. $10 \mathrm{~min}$ later, the buffer was replaced and the clot incubated for a further $10 \mathrm{~min}$. The washed clot was finally added to a $16 \times 95-\mathrm{mm}$ polystyrene tube containing $0.6 \mathrm{ml}$ of plasma obtained from another portion of the same blood sample. The radioactivity associated with the washed clot was $\sim 60 \%$ of the total amount added to the blood. The final sample was incubated at $37^{\circ} \mathrm{C}$, and at hourly intervals, $10 \mu \mathrm{l}$ of plasma were withdrawn for the estimation of ${ }^{125}$ I-fibrin-split products.

Isolation of vitamin $\mathrm{K}$-dependent plasma proteins and assay of PC. Blood was collected into $0.4 \%$ citrate and $10 \mathrm{mM}$ benzamidine (final concentration). Prothrombin complex was prepared from plasma by barium citrate adsorption, sodium citrate wash, and EDTA elution (8). $5 \mathrm{mM}$ benzamidine was added to the wash and elution steps. The prothrombin complex was dialyzed against $20 \mathrm{mM}$ Tris- $\mathrm{HCl}$ buffer, $\mathrm{pH}$ 7.4 , containing $150 \mathrm{mM} \mathrm{NaCl}$ and $0.01 \%$ Tween 80 . Full activation of $\mathrm{PC}$ in the barium citrate plasma eluate was obtained by incubation with thrombin $(5 \mathrm{U} / \mathrm{ml})$ for $1 \mathrm{~h}$ at $37^{\circ} \mathrm{C}$. Thrombin was then neutralized by an additional 10-min incubation in the presence of antithrombin III $(15 \mu \mathrm{g} / \mathrm{ml})$. PCa was measured by both amidolytic (8) and clotting assays. The latter were performed by estimating the prolongation of the APTT of normal monkey plasma following addition of $20 \mu$ l of thrombinactivated barium citrate eluate. An example is illustrated in Fig. 1. To determine the levels of PCa generated in vivo following T-TM infusion, a barium citrate eluate of monkey plasma was prepared as outlined above. PCa activity in this sample was measured omitting activation with thrombin and was expressed as percent of the activity generated in the preinfusion sample after maximal activation with thrombin in vitro.

\section{Results}

Intravenous administration of human PCa to squirrel monkeys (3 $\mu \mathrm{g} \mathrm{PCa} / \mathrm{ml}$ blood) resulted in prolongation of the APTT
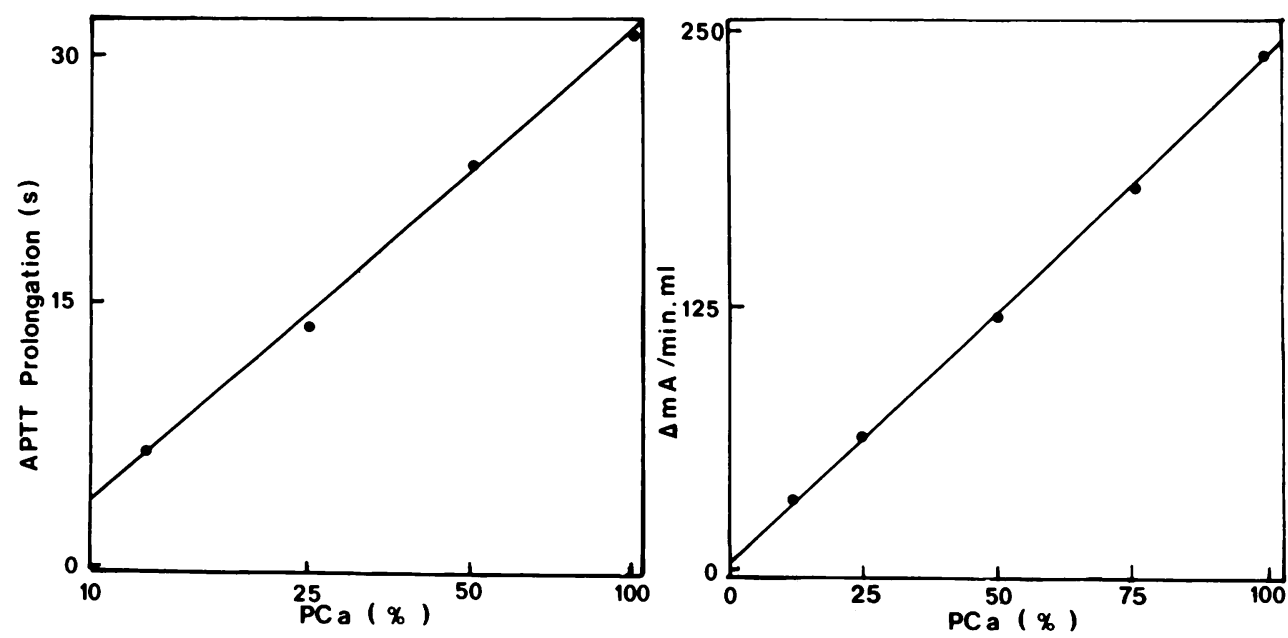

Figure 1. Anticoagulant and amidolytic activity of monkey PCa. Thrombin-activated barium citrate eluate of monkey plasma (see text) was used as source of PCa. Left: Effect of different dilutions of $\mathrm{PCa}$ on the APTT of normal monkey plasma. $20 \mu$ l of PCa solution, at the indicated concentrations, were added to $100 \mu \mathrm{l}$ plasma (preactivated with kaolin for 5 $\min$ at $37^{\circ} \mathrm{C}$ ) before determination of APTT. $100 \%$ is assumed as the amount of PCa present in the undiluted barium citrate plasma eluate. Right: Amidolytic activity of PCa. 


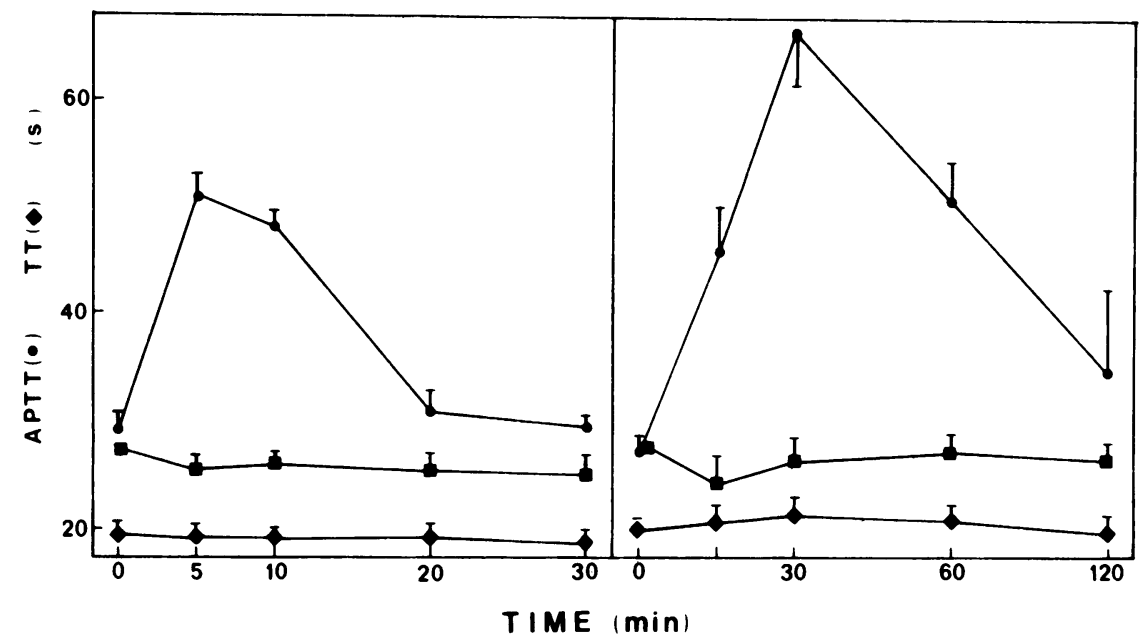

Figure 2. Effect of human PCa injection $(3 \mu \mathrm{g} / \mathrm{ml}$ blood) (left) and of T-TM infusion (2.9 $\mu \mathrm{g} / \mathrm{kg}$ body weight per $\mathrm{min}$ ) (right), on plasma coagulation and PA activity in squirrel monkeys. Values are the mean \pm SD of three experiments.

without relevant changes in TT and PA activity (Fig. 2). Platelet count, FV, and fibrinogen levels were also unchanged. In vitro, the addition of an equivalent amount of human PCa to monkey plasma induced a comparable prolongation of APTT without affecting the TT. No anticoagulant activity was expressed by unactivated PC (not shown).

The fibrinolytic response to endogenous PCa was investigated by infusing the squirrel monkeys with T-TM. Infusion of T-TM over $30 \mathrm{~min}$ at a rate of $2.9 \mu \mathrm{g} / \mathrm{kg}$ body weight per min (corresponding to $2 \mathrm{U}$ of bound thrombin/ $\mathrm{kg}$ per $\mathrm{min}$ ) induced a marked prolongation of the APTT without affecting plasma TT (Fig. 2).

Blood anticoagulation was caused by PC activation as indicated by the following findings (Fig. 3). Plasma samples (20 $\mu$ l) that were drawn 30 min after the start of the infusion prolonged the APTT, but not the TT, of $100 \mu$ l control monkey plasma. Incubation of postinfusion plasma at $37^{\circ} \mathrm{C}$ resulted in progressive disappearance of this anticoagulant effect on control plasma. Adsorption of postinfusion plasma with barium citrate and elution with EDTA yielded comparable levels of anticoagulant activity. The partially purified anticoagulant was totally inhibited by rabbit IgG directed against human PC (Fig. 4). In addition, it exhibited amidolytic activity towards the synthetic substrate S-2266 and was not neutralized by antithrombin III.

By clotting and amidolytic assays, it was found that peak levels of PCa activity recovered from postinfusion plasma amounted to between 20 and $30 \%$ of the total PC present in preinfusion samples. Despite this high level of PCa, T-TM infusion was not associated with an increase of circulating PA (Fig. 2). Lack of fibrinolytic response was also confirmed by measuring ${ }^{125}$ I-fibrin degradation products released from radiolabeled clots (Fig. 5). No change in platelet count, FV, and
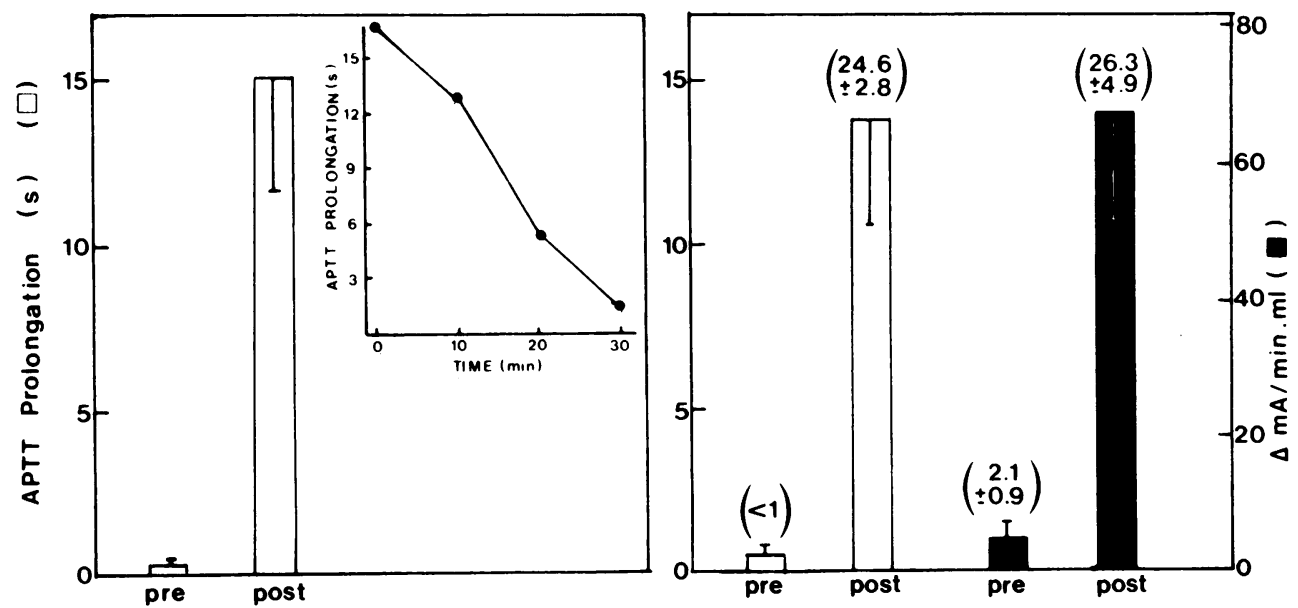

Figure 3. Anticoagulant activity generated by T-TM infusion. Left: Effect of pre- and postinfusion $(30 \mathrm{~min})$ plasma on the APTT of normal plasma. Inset: Disappearance of the anticoagulant activity in postinfusion plasma upon incubation at $37^{\circ} \mathrm{C}$. Right: Anticoagulant and amidolytic activity recovered from pre- and postinfusion $(30 \mathrm{~min}$ ) plasmas by barium citrate adsorption and EDTA elution. In brackets, the amount of PCa expressed as percent of that obtained from the preinfusion sample after maximal activation in vitro with thrombin is reported. Values are the mean $\pm S D$ of three experiments. 


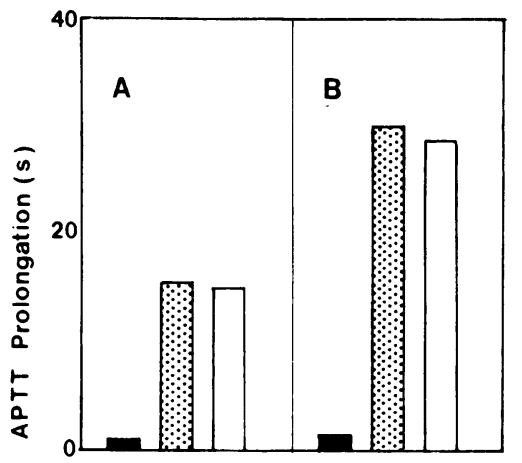

Figure 4. Immunological identification of the anticoagulant activity generated by T-TM infusion. $(A) \mathrm{A}$ barium citrate eluate of post-infusion ( $30 \mathrm{~min}$ ) plasma was incubated for $2 \mathrm{~h}$ at $37^{\circ} \mathrm{C}$ with an equal volume of rabbit anti-human PC lgG $(1 \mathrm{mg} / \mathrm{ml})$ (๘), nonimmune rabbit $\operatorname{lgG}(1 \mathrm{mg} / \mathrm{ml})($ (⿴) $)$, or buffer ( $\square$ ). Residual anticoagulant activity was evaluated by measuring the prolongation of the APTT of normal monkey plasma upon addition of $40 \mu \mathrm{l}$ of the incubation mixture. $(B)$ Effect of anti-PC IgG on the anti-coagulant activity of thrombin-activated barium citrate eluate of preinfusion plasma (complete conversion of PC to $\mathrm{PCa}$ ).

fibrinogen levels were observed during the infusion. In two additional experiments, monkeys were infused with a complex of human thrombin and monkey thrombomodulin. In this case, also, generation of PCa (18-29\% of total) did not lead to increased levels of PA in blood (between 80 and $110 \%$ of preinfusion value). To exclude the theoretical possibility that circulating T-TM complex was interfering with the release of PA, we measured the fibrinolytic response to 1-desamino 8-D arginine vasopressin (DDAVP) in monkeys that had received an infusion of T-TM. DDAVP (10 $\mu \mathrm{g} / \mathrm{kg}$ body weight) was injected immediately after the end of T-TM infusion and blood samples were taken 2 min later for PA assay. In two separate experiments, DDAVP induced a marked increase of blood PA activity (330 and $395 \%$ of pre(T-TM)-infusion value). The addition to plasma euglobulins of rabbit $\mathrm{Ig}(5 \mu \mathrm{g} / \mathrm{ml}$ final concentration) directed against human tissue PA resulted in the inhibition of $>80 \%$ of the activity present in post-DDAVP samples and inhibition of

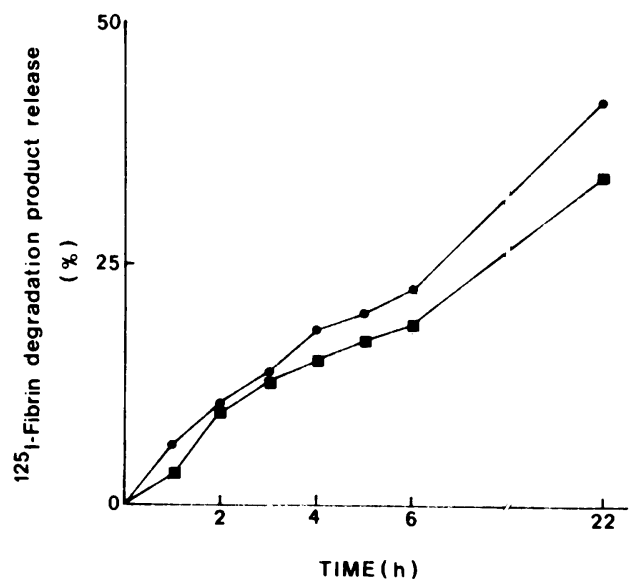

Figure 5. Effect of T-TM infusion ( $2.9 \mu \mathrm{g} / \mathrm{kg}$ body weight per min) on whole blood clot lysis. Curves represent the release of ${ }^{125}$ I-fibrinsplit products from clots made before $(\bullet)$ and immediately after the end of infusion (a). See Methods for details.
$30-45 \%$ of the activity present in pre- and post-T-TM samples. In all instances, $<5 \%$ of the activity was quenched by comparable amounts of rabbit anti-human urokinase Ig or nonimmune rabbit Ig.

Infusion of thrombomodulin alone $(0.57 \mu \mathrm{g} / \mathrm{kg}$ body weight per min, a dose comparable with the free thrombomodulin present in the T-TM complex infused in the above mentioned experiments) did not noticeably affect any of the parameters studied.

In our experiments, infusion of low doses of thrombin (1 or $2 \mathrm{U} / \mathrm{kg}$ body weight per min over 20 or $60 \mathrm{~min}$ ) did not elicit a selective prolongation of the APTT as a result of PC activation and was not associated with an increase of PA activity in blood.

The following experiments were carried out to assess whether a blood component which might be involved in the PCa-induced release of PA could be missing in the monkey. Human blood was incubated with $\mathrm{PCa}(6 \mu \mathrm{g} / \mathrm{ml})$ for $10 \mathrm{~min}$ at $37^{\circ} \mathrm{C} .5 \mathrm{ml}$ of plasma obtained from this latter sample were infused (1 $\mathrm{ml} / \mathrm{min}$ ) in the squirrel monkey and blood aliquots were withdrawn at predetermined intervals for PA assay. Fig. 6 shows that no changes in plasma PA activity occurred over the period of the experiment.

\section{Discussion}

Infusion of human PCa into squirrel monkeys at a dose of 3 $\mu \mathrm{g} / \mathrm{ml}$ blood did not result in an increase of circulating PA activity. The lack of fibrinolytic response did not appear to be due to species specificity because the anticoagulant activity of human PC was strongly expressed in the monkey. Furthermore, no PA release was observed following activation of endogenous PC by T-TM infusion. T-TM complex has been demonstrated to be a very potent activator of PC devoid of clotting and plateletactivating activities $(3,10,15,16)$. In our experiments, infusion of T-TM induced a pronounced activation of $\mathrm{PC}$ as evidenced by the marked prolongation of the APTT. Generation of PCa

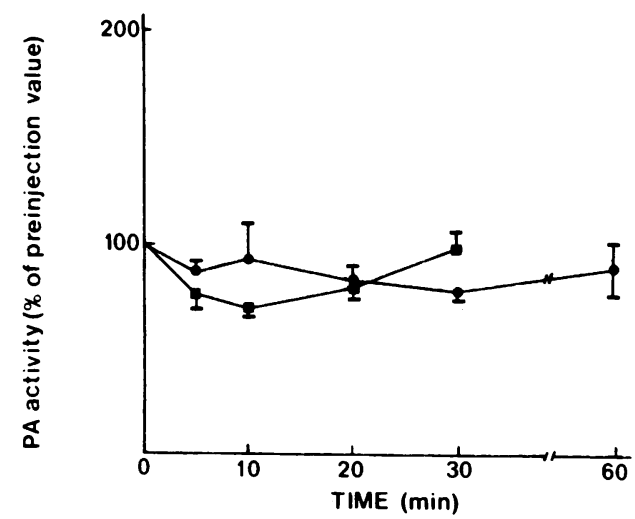

Figure 6. PA response to infusion of plasma derived from PCa stimulated whole human blood (๑) (see text for details) and of control human plasma ( () . Values represent mean and range of two separate experiments. 
was further documented by the following findings. The anticoagulant activity formed in vivo acted on thrombin generation, not on thrombin activity, and like PCa, was slowly inhibited by plasma at $37^{\circ} \mathrm{C}$. Following barium citrate adsorption and EDTA elution of postinfusion plasma, it was demonstrated that this anticoagulant was completely inhibited by rabbit anti-human PC IgG, that it expressed amidolytic activity, and that it was not inhibited by antithrombin III. The anticoagulant activity generated in vivo by T-TM corresponded to $20-30 \%$ of that obtained after maximal activation of $\mathrm{PC}$ in vitro. Infusion of low doses of thrombin did not lead to selective activation of $\mathrm{PC}$ or release of PA.

The possibility that the squirrel monkey is a poor responder to PA releasing agents is excluded. Previous investigations by our laboratory (17) have indeed shown that infusion of known stimulators of PA release, such as vasopressin or DDAVP, induce a marked fibrinolytic response in the squirrel monkey (up to threefold increase in the plasma levels of PA). Furthermore, we demonstrated that the increase of circulating PA is mainly due to the release of tissue-type PA. Finally, evidence was provided that the presence in the circulation of soluble T-TM, which at least in physiological conditions is not a circulating complex (3), does not affect the fibrinolytic potential of the animals.

Bovine PCa has been demonstrated to induce PA release in dogs via a second messenger present in blood (4). It is possible that, in the squirrel monkey, this second messenger is missing or does not interact with PCa. If this is so, the question arises as to whether, in humans, $\mathrm{PCa}$ is capable of inducing generation of a PA-releasing factor in blood. In our experiments, no fibrinolytic response was observed in monkey following infusion of plasma obtained from PCa-stimulated whole human blood. Such evidence is very suggestive but not totally conclusive to exclude the existence in human blood of a second messenger for PCa-induced release of PA.

In conclusion, our findings indicate that $\mathrm{PCa}$ does not have profibrinolytic properties in squirrel monkeys, and thus, they raise some questions on the role of this enzyme in the regulation of PA release in man.

\section{References}

1. Kisiel, W., W. Canfield, L. Ericsson, and E. Davie. 1977. Anticoagulant properties of bovine plasma protein $\mathrm{C}$ following activation by thrombin. Biochemistry. 16:5824-5831.
2. Marlar, R. A., A. J. Kleiss, and J. H. Griffin. 1982. Mechanism of action of human activated protein $\mathrm{C}$, a thrombin dependent anticoagulant enzyme. Blood. 59:1067-1072.

3. Esmon, C. T., and W. G. Owen. 1981. Identification of an endothelial cell cofactor for thrombin-catalyzed activation of protein $\mathrm{C}$. Proc. Natl. Acad. Sci. USA. 78:2249-2252.

4. Comp, P. C., and C. T. Esmon. 1981. Generation of fibrinolytic activity by infusion of activated protein $\mathrm{C}$ into dogs. J. Clin. Invest. 68:1221-1228.

5. Comp, P. C., R. M. Jacocks, G. L. Ferrel, and C. T. Esmon. 1982. Activation of protein $C$ in vivo. J. Clin. Invest. 70:127-134.

6. Taylor, F. B., R. C. Carrol, Jr., J. Gerrard, C. T. Esmon, and R. D. Radcliffe. 1981. Lysis of clots prepared from whole blood and plasma. Fed. Proc. 40:2092-2098.

7. Marciniak, E. 1972. Inhibition of human blood coagulation elicited by thrombin. J. Lab. Clin. Med. 79:924-934.

8. Sala, N., W. G. Owen, and D. Collen. 1984. A functional assay of protein $\mathrm{C}$ in human plasma. Blood. 63:671-675.

9. Fenton, J. W., II, M. J. Fasco, A. B. Stackrow, D. L. Aronson, A. M. Young, and J. S. Finlayson. 1977. Human thrombins. Production, evaluation and properties of $\alpha$-thrombin. J. Biol. Chem. 252:35873598.

10. Esmon, N. L., W. G. Owen, and C. T. Esmon. 1982. Isolation of a membrane-bound cofactor for thrombin-catalyzed activation of protein C. J. Biol. Chem. 257:859-864.

11. Ceustermans, R., M. Hoylaerts, M. De Mol, and D. Collen. 1982. Preparation, characterization and turnover properties of heparinantithrombin III complexes stabilized by covalent bonds. J. Biol. Chem. 257:3401-3408.

12. Rijken, D. C., and D. Collen. 1981. Purification and characterization of the plasminogen activator secreted by human melanoma cells in culture. J. Biol. Chem. 256:7035-7041.

13. Hjelm, H., K. Hjelm, and J. Sjoquist. 1972. Protein A from staphylococcus aureus. Its isolation by affinity chromatography and its use as an immunosorbent for isolation of immunoglobulins. FEBS (Fed. Eur. Biochem. Soc.) Lett. 28:73-76.

14. Astrup, T., and S. Müllertz. 1952. Fibrin plate method for estimating fibrinolytic activity. Arch. Biochem. 40:346-351.

15. Esmon, C. T., N. L. Esmon, and K. W. Harris. 1982. Complex formation between thrombin and thrombomodulin inhibits both thrombin-catalyzed fibrin formation and factor $\mathrm{V}$ activation. J. Biol. Chem. 257:7944-7947.

16. Esmon, N. L., R. C. Carrol, and C. T. Esmon. 1983. Thrombomodulin inhibition of platelet activation by thrombin. Thromb. Haemostasis. 50(1):81. (Abstr. 239)

17. Colucci, M., J. M. Stassen, J. Salwa, and D. Collen. 1984. Identification of plasminogen activator releasing activity in the neurohypophysis. Br. J. Haematol. In press. 